the exhibits in Section A were collections of drugs \&c. by Messrs. Allen and Hambury, Burroughs, Wellcome, and Co., T. Christy and Co., Corbyn, Stacey, and Co., Evans, Sons, and Co., Ferris, Boorne, Townsend, and Boucher, Glasgow Apothecaries' Company, C. Green and Co., C. J. Hewlett and Sons, Lorimer and Co., J. Richardson and Co., Savory and Moore, W. H. Schieffelin and Co., W. R. Warner and Co., and others. In Section B, Professor G. Buchanan exhibited calculi removed by lithotomy and lithotrity; Dr. H. C. Cameron, calculi and other specimens; Mr. WV. Cathcart, a series of specimens illustrative of tubercular synoritis of the knee; Dr. J. Coats, a series of specimens of embolism and aneurysm of cerebral vessels, another series of tumours of the brain, and an extensive collection of uterine and ovarian tumours; Mr. A. Edington of Edinburgh showed a complete series of cultures of microorganisms, and Mr. Maylard of Glasgow had similar preparations. Dr. S. Man, Mr. Stuart Nairne, Dr. Mackie Whyte, Dr. D. Fraser, and Mr. T. W. Nunn showed various specimens; whilst Dr. Newman exhibited a series of specimens of diseases of the kidney; Dr. Beavan Rake, of leprosy; Dr. Lindsay Steven, of diseases of the heart; Drs. Norris Wolfenden and Sidney Martin, of laryngeal growths. In Section $\mathbf{C}$, anatomical preparations and casts were shown by Dr. Bowles, Professor Chiene, Professor Hamilton, Mr. W. A. Lane, Dr. Macintyre, Dr. Paterson, and Dr. Reid. In Section D, microscopical and bacteriological instruments and appliances were shown by Messrs. R. and J. Beck, H. Crouch, W. Hume (Edinburgh), Ross and Co., Jas. White (Glasgow), and A. Fraser (Edinburgh); whilst Dr. Carlier, Demonstrator of Physiology at the University of Edinburgh, exhibited a series of normal tissues and organs. In Section $E$, instruments \&c. were shown by many firms, including Arnold and Sons, J. Coxeter and Son, Down Bros., Ferris, Boorne, Townsend, and Boucher, J. Gardner, W. B. Hilliard and Sons, Lynch and Co., Mayer and Meltzer, Pickard and Curry, K. Schall, and J. Weiss and Son; whilst medical literature was well represented in the complete collections of new works shown by Messrs. Holmes (Glasgow), H. K. Lewis (London), J. Maclehose and Sons (Glasgow), Macmillan and Co. (London), Young J. Pentland (Edinburgh), G. Redway (London), and A. Stenhouse (Glasgow). In Section F, numerons sanitary appliances and inventions were exhibited, this collection being arranged in a marquee erected in the quadrangle. A complete catalooue of the museum was given to each member, who also received a Handbook to the Medical Institutions of Glasgow, which had been specially prepared in view of this meeting.

\section{THE BOWER AND KEATES INDEMNITY FUND.}

THE following statement by the Committee of the above Fund has been sent to us for publication:-

The case of Messrs. Bower and Keates was brought to the notice of the profession by a circular sent out in December, 1883 , to all medical practitioners in Great Britain and Ireland, whose names appeared in Messrs. Clurehill's Medical Directory for that year. The circular stated that on Aug. 3Ist, 1882, a child was suffering from sporadic laryngitis, and suffocation was impending. With the consent of the parents tracheotomy was performed by Dr. Bower, assisted by Mr. Keates. 'The operation was done skilfully and successfully, the child surviving for twenty-four hours, and subsequently dying of the further effects of the disease. A civil action was afterwards brought against these gentlemen by the father of the child for allowing him to clear the tracheotomy tube by suction in order to avert the impending death of his child. The jury disagreed on this trial, and it is in eridence on this occasion that the parents expressed their satisfaction with the treatment which their child had received. Failing in this action, the parents brought a criminal prosecution against Dr. Bower and Mr. Keates, and the mother of the child on Sept. 11th, 1883, swore an information before the sitting magistrate at the Lambeth Police-court, charging them with the manslaughter of the child. When Dr. Bower and Mr. Keates appearer to answer this charge, they found, to their astonishment, that it was adopted and pressed against them by the Public Frosecutor. Amongst other grave consequences of the intervention of the Public Prosecutor these two should be noticed-namely (1), that these gentlemen, though charged as criminals, could not bring an action for malicious prosecution; and (2) that they were debarred the usual right of claiming payment of their expenses from those who had so unjustly prosecuted them.

It was felt that a mere verbal expression of sympathy with these gentlemen would not under the circumstances be sufficient, seeing that they had incurred legal expenses estimated at nearly $\mathfrak{E} 1000$. It was in view of the propriety of aiding. Dr. Bower and Mr. Keates in this matter that the following resolution was passed at a meeting held at Sir William Jenner's residence on Monday, Dec. 10th, 1883 : " That a committee be formed for the purpose of collecting subseriptions to defray the legal expenses incurred by Dr. Bower and Mr. Keates in their defence from the charges recently brought against them, and of preparing a statement by which the subscribers may express their sympathy with those gentlemen, and their conviction that the treatment of the case for which they were prosecuted was right." The circular was signed by Sir William Jenner, Sir James Paget, Dr. Richard Quain, Mr. John Marshall Dr. J. M. Bright, Mr. Thomas Bryant, Dr. Wilson Fox, Dr. J. Grey Glover, Mr. Jonathan Hutchinson, Mr. J. T. Jackson, Dr. Walter Moxon, Mr. Sidney Turner, Dr. F. A. Mahomed, and Dr. R. W. Burnet. So hearty was the response to this appeal that within a week the required sum was subscribed, and before the list could be closed $\$ 1726$ had been received from 1954 subscribers.

The committee hoped to have wound up the business with which they were entrusted at a much earlier date, but great delay was entailed by the fact that a new trial was. threatened, and that difficulties were put in the way of having the costs taxed. The mere legal costs, as certified by the taxing master, amounted to $£ 931 \mathrm{los} .11 \mathrm{~d}$., and that sum was paid over to Messrs. Bower and Keates.

Some months ago the committee, having paid all costs and other expenses of the fund, found that they had a balance of about $£ 500$. They issued a circular to all the subscribers, stating that it was proposed to give part of this sum to assist several similar deserving cases, on belhalf of which application had been made, and to divide the surplus amongst medical charities; but that if any subscriber objected to these proposals, he could receive back the proportion of his subscription on applying to the hon. secretary. The majority of the replies received were in favour of the distribution suggested by the committee, and they have acted accordingly, giving $\$ 150$ to $\mathrm{Mr}$. Ralph Hodgson, late of Lewisham, who successfully defended himself from a charre of indecent assault at an expense of about $£ 500$, $£ 50$ towards the expenses of the defendants in the case of Gibson and wife $v$. Jeffries and Hills, $£ 50$ to Dr. Brown in the case of Lennard $v$. Brown and others, and $£ 50$ to Dr. West Symes in the case of Moss $v$. West Symes. The balance the committee have distributed between the British Medical Benevolent Fund, the Royal Medical Benevolent Fund Society of Ireland, the Royal Medical Benevolent College, Epsom, and the Society for the Relief of Widows and Orphans of Medical Men.

The committee cannot close this statement without a brief reference to the lamented deaths of Dr. Wilson Fox, Dr. Moxon, and Dr. Mahomed, who to a large extent initiated the movement which they did not live to see carried out, but to which they zealously contributed by their exertions so long as their valuable lives were spared. (Signed)

August, 1888. WILLIAM JENNER, Chairman. RICHARD QUAIN, Treasurer. R. W. Buryet, Hon. Sec.

\section{"AN EASY METHOD FOR PRODUCING LARGE ANATOMICAL DIAGRAMS."}

To the Editors of THE LANCET.

SIRS,-There is a simpler method than that suggested by your correspondent, Mr. Thomas, for enlarging drawings for lecture purposes-riz., the substitution of gelatine films, which are easily obtainable, for the mica sheets covered with varnish which he recommends. These cost next to nothing, are always ready, and the surface is easily drawn on by a pen and ordinary or Indian ink. The drawing board bearing the paper is best hung on the wall. It is easy by this method to obtain an outline of a most complicated 
drawing in a few minutes. I generally use a "Silber" argand gas-burner in the lantern as more manageable than the three-wicked oil-lamp. I do not think it is generally known by medical and other lecturers that lantern slides can be shown without darkening the room if only the screen be shaded, and a disc of not more than five feet diameter be used. A "blow-through" oryhydrogen jet is very easy to manage, and the lantern can be placed on the lecture-table and manipulated by the lecturer. Good diagrams are very expensive, and the paper alone costs nearly as much as a photographed lantern slide.

Leeds, Aug., 18s8. I am, Sirs, yours faithfully,

ERNesT H. JACOB, M.D.

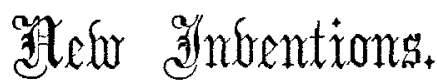

\section{GODFREY'S PATENT CHLORIDE OF AMMONIUM INHALER.}

THE vapour of chloride of ammonium has recently been largely employed in the treatment of catarrh of the mucous membrane of the ear, nose, and throat, and it has also been used in bronchitis, asthma, and hay fever. Hitherto there has been some difficulty in arranging the conditions which shall give a plentiful cloud of chloride of ammonium in a neutral state, excess of acid or of ammonia requiring careful removal. From the accompanying illustration it will be seen that by an exceedingly simple arrangement a perfectly neutral cloud is obtained. The inhaler consists essentially of three tubes passing through the indiarubber

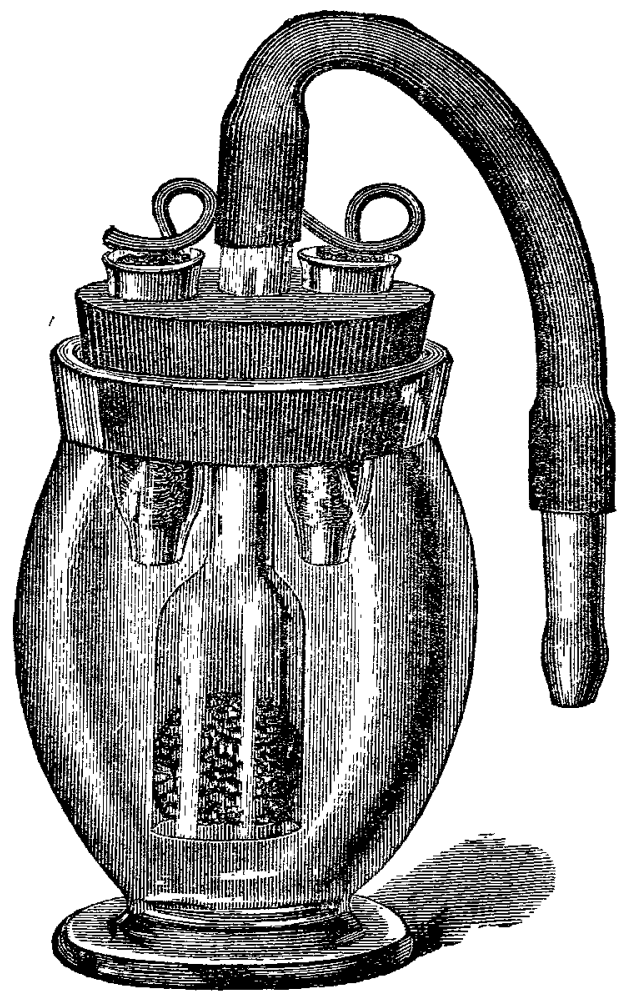

cork which closes the inhaler bottle. The centre bell glass is lightly plugged with a piece of sponge moistened with cold water; the two smaller tubes contain cylinders of a porous substance on protected wire-holders, and are charged by being dipped respectively into hydrochloric acid and ammonia. Upon suction being exerted at the mouth-piece, fumes of these two fluids pass into the inhaler and mingle and combine chemically, giving rise to dense white fumes of chloride of ammonium. Inhalation being continued, these fumes are necessarily drawn through the centre bell tube into the air passages, excess of acid or of alkali being arrested by the moistened sponge. We have carefully tested the inhaler, and find that the resulting fumes are completely devoid of any irritating or offensive properties. The body of the inhaler containing no water, any aromatic volatile substance may be introduced as desired. The inhaler is supplied in a neat cedar-wood box, containing supplies of acid and ammonia, the former being in a green glass bottle which corresponds with the green tube of the inhaler. The only word of caution we would venture to give in connexion with this instrument is that it is absolutely essential that the sponge in the centre tube should be freshly moistened every time the inhaler is used. Messrs. Godfrey and Cooke, of 30, Conduit-street, London, are the patentees and sole makers of this inhaler. Its price is moderate.

\section{NEW RECTAL SPECULUM.}

THERE are various symptoms complained of by patients referable to the rectum as a cause oi trouble, and requiring a visual examination of the parts. In hospital practice, it is an easy matter to anæsthetise the patient, and by stretch. ing or forcibly rupturing the sphincter and obtain a full view of the rectal walls. In private practice few patients will submit to such a severe proceeding unless driven to it by extreme suffering, so that if a satisfactory examination is to be made, without much pain to the patient or the necessity for ether or chloroform, it is essential that the examination should be made with a speculum which will give the least annoyance. The illustration represents a light wire speculum, with parallel action and easy of introduction, which, when properly used, will, with the minimum amount of discomfort to the patient, afford the examiner a good view of the rectal walls. The screw, with winged nut, which divaricates the blades, is kept towards the sacrum of the patient, and when the instru-

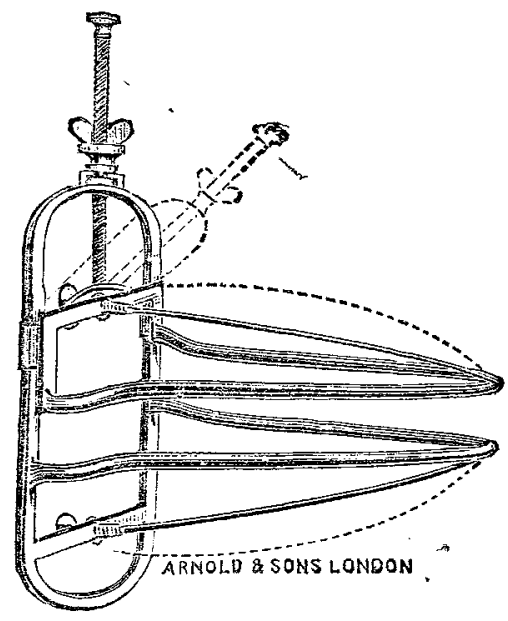

ment is in situ the necessary amount of expansion can be effected at will, the blades working parallel, while an anterior and posterior screw at the base of the instrument will, when worked, bend the flat rod (running from top to base of each blade) into a convex shape, and so bulge out and stretch the rectal walls as to obliterate the usual folds, and that without any additional strain on the sphincter itself. I know of no other rectal speculum working on this principle, as the lax part of the rectum above the sphincter is never put on the stretch by the ordinary rectal specula in use, so that a fissure or small growth \&c. could be easily overlooked, and the patient persuaded that nothing was wrong there. The speculum can be taken asunder for portability or for cleaning, and I fancy the instrument I have endeavoured to describe will be found on trial to fulfil the advantages claimed. It is made by Messrs. Arnold and Sons, London.

Dublin. 